Students' science process skill and analytical thinking ability in chemistry learning Irwanto, , Eli Rohaeti, , Endang Widjajanti, and, and Suyanta

Citation: AIP Conference Proceedings 1868, 030001 (2017); doi: 10.1063/1.4995100

View online: http://dx.doi.org/10.1063/1.4995100

View Table of Contents: http://aip.scitation.org/toc/apc/1868/1

Published by the American Institute of Physics

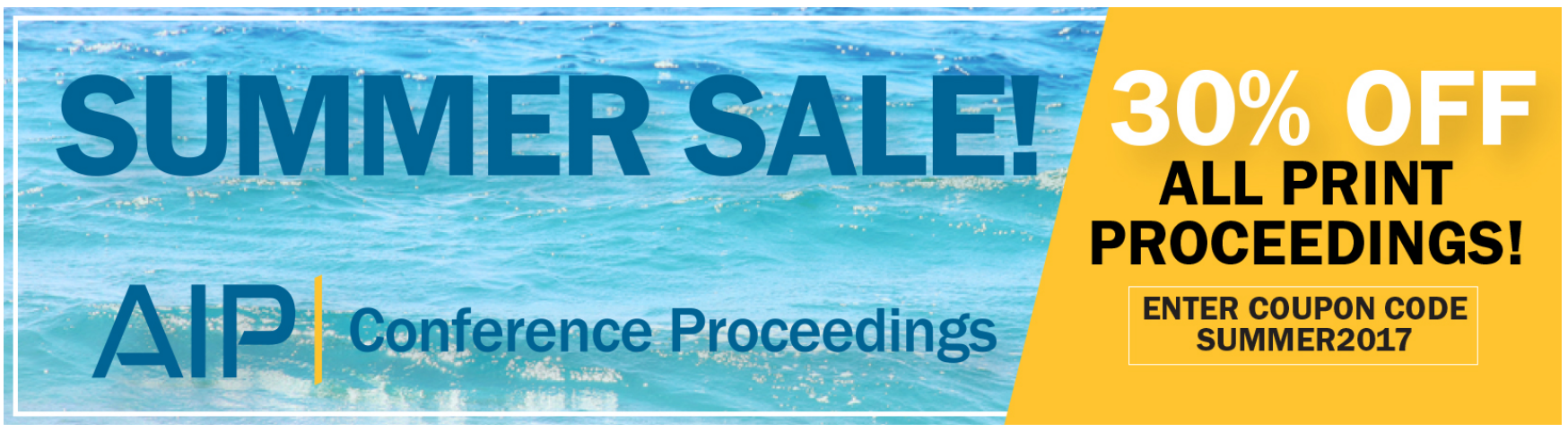




\title{
Students' Science Process Skill and Analytical Thinking Ability in Chemistry Learning
}

\author{
Irwanto $^{1}$, Eli Rohaeti ${ }^{2}$, Endang Widjajanti ${ }^{2}$, a), Suyanta $^{2}$ \\ ${ }^{1}$ Doctoral Student of Educational Science, Yogyakarta State University, Yogyakarta, Indonesia \\ ${ }^{2}$ Department of Chemistry, Yogyakarta State University, Yogyakarta, Indonesia \\ ${ }^{a}$ Corresponding author: endang_wijayanti@uny.ac.id
}

\begin{abstract}
Science process skill and analytical thinking ability are needed in chemistry learning in $21^{\text {st }}$ century. Analytical thinking is related with science process skill which is used by students to solve complex and unstructured problems. Thus, this research aims to determine science process skill and analytical thinking ability of senior high school students in chemistry learning. The research was conducted in Tiga Maret Yogyakarta Senior High School, Indonesia, at the middle of the first semester of academic year 2015/2016 is using the survey method. The survey involved 21 grade XI students as participants. Students were given a set of test questions consists of 15 essay questions. The result indicated that the science process skill and analytical thinking ability were relatively low ie. $30.67 \%$. Therefore, teachers need to improve the students' cognitive and psychomotor domains effectively in learning process.
\end{abstract}

\section{INTRODUCTION}

Chemistry is a subject related to laboratory activities. The purpose of these activities is to teach a variety of skills and conceptual understanding through practical activities. In the chemistry learning, one of the materials related to the laboratory activities is the reaction rate. To teach this subject, the teachers should encourage the students to participate in various experiments actively [1]. Through the experiments, the students will find a wide range of issues and solve many problems independently. In addition, the students will have some direct experiences in the process of the invention concept. Furthermore, the concept gained through the practical activities would give the effect of long-term memory.

In the chemical education, the laboratory activity is much more important than conventional learning due to providing an opportunity for students to perform a variety of skills [2]. The essential skills related to laboratory activity is science process skill. Science process skill is a cognitive and psychomotor skills used in problem solving [3]. Indicators of science process skill include planning experiments, predicting, classifying, interpreting, measuring, inferring, applying concepts, creating graphs, and communicating data. Thus, the teachers must teach science skills such as facts, concepts, and theories to encourage students conduct scientific investigations [4].

Process skills describe students' thinking activity and require reasoning. The teachers play an important role in the classroom to teach science process skill through a series of scientific learning process [5]. In addition to skills, the students also have to master the knowledge to develop an understanding of scientific concepts. Knowledge that can be developed through laboratory activities are analytical thinking ability. Analytical thinking ability is the ability to analyze, assess, evaluate, compare, and contrast abstract concepts [6]. Indicators of analytical thinking ability include differentiating, organizing, and attributing chemistry concepts.

Analytical thinking involves a series of mental processes in finding solutions to many problems [6]. Science process skill and analytical thinking are the two interrelated things. Through an active learning in the laboratory, the students are expected to have the skills and develop the abilities to think [7]. In other words, science process skill cannot be separated from the practical activities because it plays a key role in chemistry learning [8]. In the chemistry learning, the students are also expected to have analytical thinking ability to be able to think abstractly in

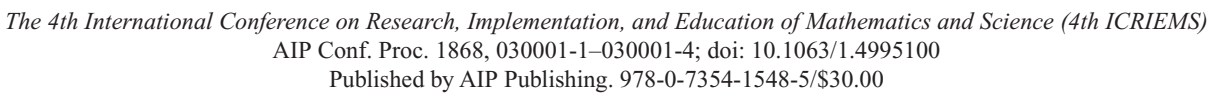


solving problems. If science process skill is integrated with analytical thinking ability will have a positive impact on the students' performance, including process skills, conceptual understanding, problem solving, and learning outcomes.

Everything need to be done to improve the performance by performing the initial diagnosis on students' achievements. The results of the diagnostic tests can be used as a reference by the teachers to improve students' science process skill and analytical thinking ability. Therefore, it is necessary to do research on the measurement of students' science process skill and analytical thinking ability early on. This is one of important step to improve and equip students with various skills and abilities needed in the $21^{\text {st }}$ century.

\section{RESEARCH METHODS}

The research was conducted in Tiga Maret Yogyakarta Senior High School, Indonesia, at the middle of the first semester of academic year 2015/2016 is using the survey method. The survey involved single class which consists of 21 grade XI students as the participants. The sampling method is using the non-probability sampling technique, ie. purposive sampling method. Therefore, students were given a set of test questions consists of 15 essay questions. Reliability coefficient was found 0.69 . The time allocation used in the study is 90 minutes. The achievement test is given to students to determine the level of mastery of science process skill and analytical thinking ability on the reaction rate. The students' science process skill and analytical thinking ability mastery levels were grouped into three categories according to Table 1.

TABLE 1. Category of abilities and skills

\begin{tabular}{ccc}
\hline No. & Interval & Category \\
\hline 1 & $>66.7 \%$ & High \\
2 & $33.3 \%-66.7 \%$ & Medium \\
3 & $<33.3 \%$ & Low \\
\hline
\end{tabular}

\section{RESULTS AND DISCUSSION}

In this study, each student's answers were analyzed according to the scoring rubric having been made in the previous stage. The analysis of the students' answers is done by using descriptive approach, by giving a score of each stage of correct answers given by each student. The measurement results are then analyzed descriptively to determine the level of students' achievement on science process skill and analytical thinking ability. 2 .

In addition, student's achievement percentage of each indicator on science process skill is presented in the Table

TABLE 2. Percentage of Science Process Skill

\begin{tabular}{clcc}
\hline No. & \multicolumn{1}{c}{ Indicators } & Score & Percentage (\%) \\
\hline 1. & Planning Experiment & 73 & 38.62 \\
2. & Predicting & 107 & 31.85 \\
3. & Classifying & 36 & 34.29 \\
4. & Interpreting & 91 & 27.08 \\
5. & Measuring & 48 & 25.40 \\
6. & Inferring & 59 & 35.12 \\
7. & Applying Concepts & 198 & 30.41 \\
8. & Creating Graphs & 26 & 24.76 \\
9. & Communicating & 19 & 30.16 \\
\hline \multicolumn{4}{c}{ Average } \\
\hline
\end{tabular}

Table 2 shows the percentage of students' achievement in the nine indicators of science process skill. The analysis results show that the highest and lowest percentage of science process skill are planning experiment $(38.62 \%)$ and creating graphs $(24.76 \%)$, respectively. The skill of creating graphs is the lowest attainment because the students are rarely trained to use science process skill in chemistry learning activities. Wulandari, Nuroso, and Siswanto [9] showed that in working on the type of charts for which the students tend to memorize the steps. The students have difficulties in describing and calculating each process. The students also do not know how to do for each process in the graph in addition to memorize. 
In general, all aspects of science process skill obtain lower category with a percentage of $30.67 \%$. The condition to indicate that the teacher has not fully optimize science process skill in the learning process. The low students' learning outcomes associated with the low teachers' ability in the mastery of science process skill [10]. In addition, students who obtaining low scores of science process skill test due to rarely do laboratory-based learning activities [11]. In general, the comparison of the percentage of the average acquisition of science process skill score for each indicator is presented in Figure 1.

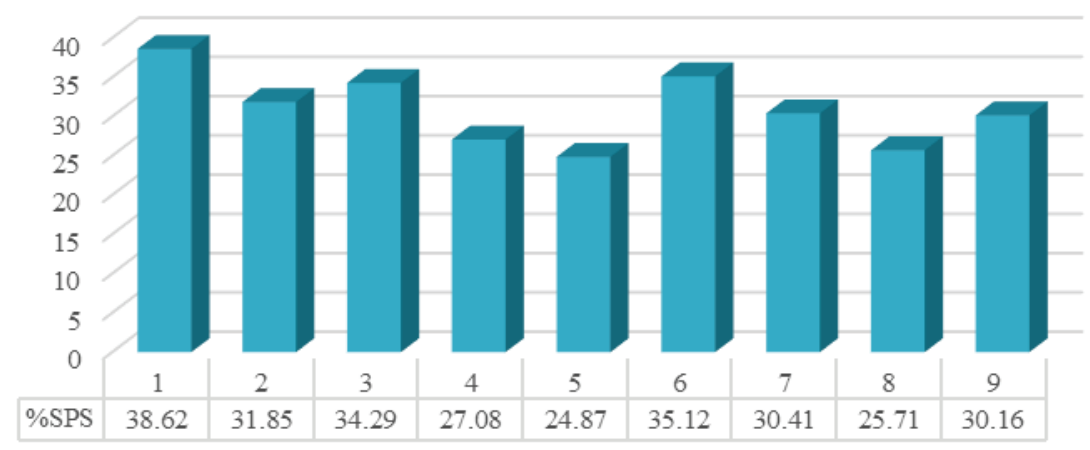

FIGURE 1. Percentage of Science Process Skill

In addition to the obtained of science process skill measurement results, from the research also was also resulted the students' analytical thinking ability. Percentage of students's analytical thinking ability in each indicator are presented in Table 3.

TABLE 3. Percentage of Analytical Thinking Ability

\begin{tabular}{|c|c|c|c|}
\hline No. & Indicators & Score & Percentage (\%) \\
\hline 1. & Differentiating & 197 & 46.90 \\
\hline 2. & Organizing & 232 & 31.56 \\
\hline 3. & Attributing & 228 & 23.10 \\
\hline & $\begin{array}{l}\text { Average } \\
\text { Category }\end{array}$ & 219 & $\begin{array}{l}30.67 \\
\text { Low }\end{array}$ \\
\hline
\end{tabular}

Table 3 shows the percentage of student's analytical thinking ability in the three indicators. The analysis shows that the highest and lowest percentage of analytical thinking ability are the ability to differentiating (46.90\%) and attributing $(23.10 \%)$, respectively.

The attributing ability is that of the lowest achievement because the students are rarely trained ones to use analytical thinking in the learning process. One of the factors affecting the low analytical thinking ability is living skills [12]. Sudibyo et al. [13] confirms that the low score of analytical thinking can be seen from the students' inability to describe data in the form of tables and graphs, cannot present data in the interconnected graphical, cannot identify the variables of the experiment, and cannot formulate the problem formulation and the hypothesis of the experiment.

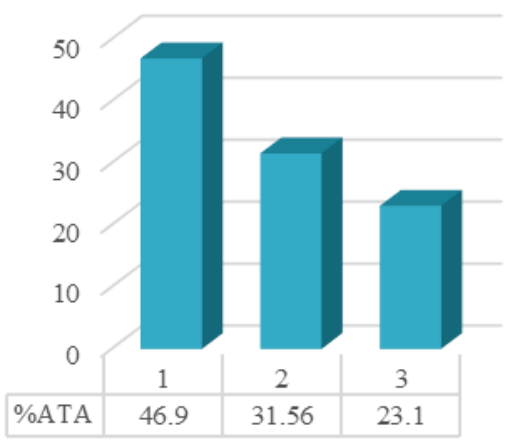

FIGURE 2. Percentage of analytical thinking ability 
In general, the measurement of all aspects in analytical thinking ability obtained the low category with the percentage of $30.67 \%$. This results indicates that the teacher has not fully optimize the students' analytical thinking ability in the learning process. Similar results were found by Rahmawati, Amirudin, and Buranda [14] that one of the low analytical thinking ability for learning in schools require less the student to develop the ability to think. The students tend to be trained to answer the questions by memorizing, so that no higher level of thinking skills cannot develop. In general, the percentage of the average acquisition of the average analytical thinking score of each indicators presented in Figure 2.

Low science process skill will affect students' analytical thinking ability in chemistry learning achievement. The research results by Oloyede \& Adeoye [15] showed a positive relationship between reasoning ability, process skills, and learning achievement. In other words, the academic success associated with science process skill $[8,16,17]$ and analytical thinking ability. Therefore, it can be concluded that students with lack science process skill and analytical thinking ability tend to have a low academic success.

\section{CONCLUSIONS AND SUGGESTIONS}

In this study, it has conducted an investigation to determine of the students' science process skill and analytical thinking ability on reaction rate. The results showed that the learning outcomes of students XI grade in Tiga Maret Yogyakarta Senior High School is relatively low. The result of science process skill and analytical thinking ability is relatively low which is $30.67 \%$. The result indicates that teachers are not optimized the students' science process skill and analytical thinking ability through practical activities in the laboratory. Therefore, teachers need to improve the students' cognitive and psychomotor domains effectively in learning process.

\section{ACKNOWLEDGMENT}

The authors would like to express profound thanks and appreciation to the DP2M DIKTI (Directorate of Higher

Education), Ministry of Research, Technology and Higher Education Republic of Indonesia through "Tim Pascasarjana" Research Grant 2016 for the financial support.

\section{REFERENCES}

1. A.H. Johnstone and A. Al-Shuaili, University Chemistry Education, 5, $42-51$ (2001).

2. G. Demircioğlu And M. Yadigaroğlu, Western Anatolia Journal of Educational Sciences, 509-516 (2011).

3. A.O. Akinbobola and F. Afolabi, American-Eurasian Journal of Scientific Research, 5, 234-240 (2010).

4. A.H. Zeidan and M.R. Jayosi, World Journal of Education, 5, 13-24 (2015).

5. R.A.A. Rauf, M.S. Rasul, A.N Mansor, Z. Othman \& N. Lyndon, Asian Social Science, 9, 47-57 (2013).

6. B. Anwar and N.S Mumthas, International Journal of Advanced Research , 2, 455-458 (2014).

7. Z.H. Ismail and I. Jusoh, Journal Of Science And Mathematics Education In S.E. Asia, 24, 67-77 (2001),

8. C. Keil, J. Haney, and J. Zoffel, Electronic Journal of Science Education, 13, 1-18 (2009).

9. N.W. Wulandari, H. Nuroso, and J. Siswanto, Prosiding Seminar Nasional Sains dan Entrepreneurship, Universitas PGRI Semarang, 21 Juni 2014, 158-165 (2014).

10. M. L. Aiello-Nicosia, R. M. Sperandeo-Mineo, and M. A. Valenza, Journal Of Research In Science Teaching, 21, 853-858 (1984).

11. Sukarno, A. Permanasari and I. Hamidah, International Journal of Scientific Engineering and Research, 1, 7983 (2013).

12. Y.M. Heong, W.B. Othman, J.M. Yunos, T.T. Kiong, R. Hassan, and M.H. Mohamad, International Journal of Social Science and Humanity, 1, 121-125 (2011).

13. R.U. Nadiroh, A. Qosyim, and N.P. Putri, Jurnal Pendidikan Sains, 2, 1-8 (2014).

14. Rahmawati, A. Amirudin and J.P. Buranda, Jurnal Pendidikan Geografi, 2, 1-12 (2013).

15. O.I. Oloyede and F.A. Adeoye, International Journal of African \& African-American Studies, 8, 1-4 (2012).

16. S. Supasorn and S. Waengchin, Procedia Social and Behavioural Sciences, 116, 744-749 (2014).

17. Guevara and C. Almario, Research Journal of Educational Sciences, 3, 6-10 (2015). 